\title{
Acil servise ateş nedeni ile yapılan başvuruların değerlendirilmesi: Bir üniversite hastanesi tecrübesi
}

\section{Evaluation of patients with fever presented to the emergency department: a university hospital experience}

\author{
Kaya Süer*, Meryem Güvenir, Yeşim Özgül, Aslı Feride Kaptanoğlu \\ Enfeksiyon Hastalıkları ve Klinik Mikrobiyoloji Bilim Dalı (Yrd. Doç. Dr. K. Süer), Tıbbi \\ Mikrobiyoloji Anabilim Dalı (Bio. M. Güvenir), Acil Servis Bölümü, (Dr. Y. Özgül), Dermatoloji \\ Anabilim Dalı (Doç. Dr. A. F. Kaptanoğlu), Yakın Doğu Üniversitesi Tıp Fakültesi, Lefkoşa \\ KKTC
}

\section{Özet}

Amaç. Bu çalışmanın amacı, Akdeniz iklimi etkisi altında olan Kuzey Kıbrıs'ta ortaya çıkan ateşli hastalıklar ve hastaların yakınmaları arasındaki ilişkinin araştırılmasıdır. Üniversite hastanesi acil servisine ateş nedeni ile başvuran hastaların başvuru yakınmaları ve etiyolojilerinin epidemiyolojik açıdan değerlendirilmesidir. Yöntem. Retrospektif olarak Temmuz 2010 ile Temmuz 2012 tarihleri arasında Kuzey Kıbrıs Türk Cumhuriyetindeki (KKTC) Tıp Fakültesi Hastanesi acil servisine başvuran hastaların başvuru nedenleri incelenmiş ve ateş yakınması olanlar çalışmaya alınmıştır. Bulgular. Acil servise başvuran 15.820 hastanın 1.224'ünde $(\% 7,7)$ ateş yakınması olduğu tespit edilmiştir. Ateşin en sık nedeni olarak ortaya konulan hastalık grubu üst solunum yolu enfeksiyonları olarak saptanmıştır. Diğer en sık görülen nedenler ise sıklık sırasına göre alt solunum yolu enfeksiyonları ve gastroenteritler olarak değerlendirilmiştir. Sonuçlar. KKTC'de bir üniversite hastanesine en sik ateş nedeni ile başvuran hasta grubu viral üst solunum yolu enfeksiyonları olarak bulundu. Bu veriler diğer ülkelerdeki hastanelerde acil servis başvuru nedenleri incelendiğinde benzer özellikler gösterdiği tespit edilmiştir.

Anahtar sözcükler: Ateş, acil servis, enfeksiyon, etiyoloji, Kıbrıs

\begin{abstract}
Aim. The purpose of this study is to investigate the relationship between emerging diseases with fever and the complaints of patients admitted to the hospital emergency department in North Cyprus. It is aimed to evaluate the admission complaints and etiology, who are admitted to the university hospital emergency department due to fever, from epidemiological point of view. Methods. In this retrospective study, the patients who applied to the emergency department of Medical Faculty Hospital, North Cyprus with complaints of fever between July 2010 and July 2012 were evaluated. Results. In 15,820 patients who admitted to the emergency department, 1,224 (\%7.73) were found to be suffering from fever. The most common group of disease cause of fever was upper respiratory tract infections. Evaluation of other most common diseases in order to frequency were lower respiratory tract infections and gastroenteritis. Conclusions. The most common cause of fever were found to be the group of patients with a viral upper respiratory tract infections in North Cyprus. It has been identified that these data are similar to the other countries hospital emergency services.
\end{abstract}

Keywords: Fever, emergency department, infection, etiology, Cyprus

Geliş tarihi/Received: 26 Şubat 2013; Kabul tarihi/Accepted: 09 Aralık 2013

*İletişim adresi:

Dr. Kaya Süer, Enfeksiyon Hastalıkları ve Klinik Mikrobiyoloji Bilim Dalı Yakın Doğu Üniversitesi Tıp Fakültesi, Lefkoşa, KKTC. E-posta: kayasuer@mynet.com 


\section{Giriş}

Ateş yakınması ile başvuran hastalar incelendiğinde, zaman kaybedilmeden tanısı konularak tedavisi başlanması gereken hastalıklar mortalite ve morbitide açısından önemlidir. Sepsis, menenjit, ensefalit, nötropenik ateş, pnömoni, invaziv gastroenteritler, üriner sistem enfeksiyonları ve spesifik viral enfeksiyonlar gibi enfeksiyon hastalıkları yanında non-enfeksiyöz ateş nedenleri de akılda tutulmalıdır. H1N1 pandemisinde olduğu gibi, acil servislere ateş ile başvuru sıklığında belirgin artışlar söz konusu olabilir [1]. Mevsimsel olarak bazı enfeksiyon hastalıklarının sıklıkları artış göstermektedir [1, 2]. Acil servislerde ateş nedeniyle başvuran hastaların birçoğunun ayaktan tedavisi mümkündür. Ancak yatırılarak tedavi edilmesi gereken hastaların ayırıcı tanısının dikkatli bir şekilde yapılması gerekmektedir.

Retrospektif bir çalışma olması nedeni ile Enfeksiyon hastalıklarından konsültasyon istenmeyen vakaların enfeksiyon dışı etiyolojileri hakkında yeterli bulunmamaktadır. Ateş epidemiyolojisi hakkında KKTC'de yapılmış hiçbir araştırma literatürde bulunamamıştır. Bu çalışmada amacımız KKTC'de bir üniversite hastanesi acil servisine ateş yakınması ile yapılan başvuruları inceleyerek en sık izlenen ateşli durumları ve özelliklerini tanımlamaktır.

\section{Gereç ve yöntem}

Bu çalışma Lefkoşa'da (KKTC) bulunan Tıp Fakültesi Hastanesi Acil Servisine Temmuz 2010 ile Temmuz 2012 tarihleri arasında başvuran hastaların kayıtlarının retrospektif olarak incelenmesi ile yapılmıştır. Resmi rakamlara göre 296.000 olan KKTC nüfusunun yanında, turizm sezonunda artan nüfus nedeni ile hastanenin verdiği sağlık hizmeti yaklaşık 600.000 kişiye ulaşmaktadır. Üçüncü basamak sağlık hizmeti veren adanın tek sağlık kuruluşu olan üniversite acil servise, ateş yakınması ile başvuran hastaların yaş, cinsiyet gibi demografik bulgularının yanında fizik muayene bulguları, laboratuvar sonuçları, klinik tanıları ve yatırılarak tedavi uygulanıp uygulanmadığı araştırılmıştır. Ateş nedeni ile başvuran hastaların timpanik ateş ölçümleri $38^{\circ} \mathrm{C}$ ve üzerinde olanlar çalışmaya alınmıştır. Acil Servis Hekimleri tarafından değerlendirilen hastalar gerekli görüldüğü takdirde Enfeksiyon Hastalıkları, Çocuk Sağlığı ve Hastalıkları, İç Hastalıkları ve diğer ilgili klinik dallar ile konsültasyonları yapılmıştır. Toplanan klinik ve laboratuvar verilerinin ortalama ve yüzdeleri sunulmuştur.

\section{Bulgular}

Temmuz 2010 ile Temmuz 2012 tarihleri arasinda Acil Servise 15.820 hasta başvurmuştur. $\mathrm{Bu}$ hastaların 1224'ünün $(\% 7,7)$ başvuru nedeni yüksek ateştir. Ateş nedeniyle değerlendirilen hastaların yaşları incelendiğinde 1 ay ile 94 yaşları (ortalama: 24,8) arasında olduğu saptanmıştır. Olguların 575'i kadın $(\% 46,9)$ ve 649'u erkek $(\% 53,1)$ olarak bulunmuştur. Ateş ile beraber en sık saptanan yakınmalar ise sıklık sırasına Tablo 1'de verilmiştir.

Ateş nedeni ile başvuruların artış gösterdiği aylar ise sırası ile ocak, temmuz ve mart ayları olarak saptandı (Şekil 1). Ateş nedeni ile başvuruların en az olduğu aylar ise sırası ile kasım, aralık ve ağustos olarak saptandı. 
Tablo 1. Ateş ile birlikte en sık saptanan yakınmalar.

\begin{tabular}{lll}
\hline Yakınma & Sayı & \% \\
\hline Boğaz ağrısı & 510 & 29,3 \\
Öksürük & 184 & 10,3 \\
Kusma & 168 & 9,6 \\
İshal & 130 & 7,4 \\
Bulantı & 126 & 7,2 \\
Karın ağrısı & 120 & 5,8 \\
Baş ağrısı & 92 & 5,6 \\
Eklem ağrısı & 86 & 4,93 \\
İdrarda yanma & 66 & 4,7 \\
Yan ağrısı & 62 & 4,4 \\
Bilinen maligniteye eşlik eden ateş & 36 & 2 \\
Burun akıntısı & 26 & 1,46 \\
Kulak ağrısı & 24 & 1,35 \\
Oryantasyon bozukluğu & 22 & 1,33 \\
Kasık ağnısı & 18 & 1,01 \\
Halsizlik & 16 & 0,9 \\
Baş dönmesi & 16 & 0,9 \\
Bayılma & 10 & 0,56 \\
Cilt iltihabı & 6 & 0,45 \\
Şuur kaybı & 6 & 0,45 \\
Kabızlık & 4 & 0,33 \\
\hline
\end{tabular}

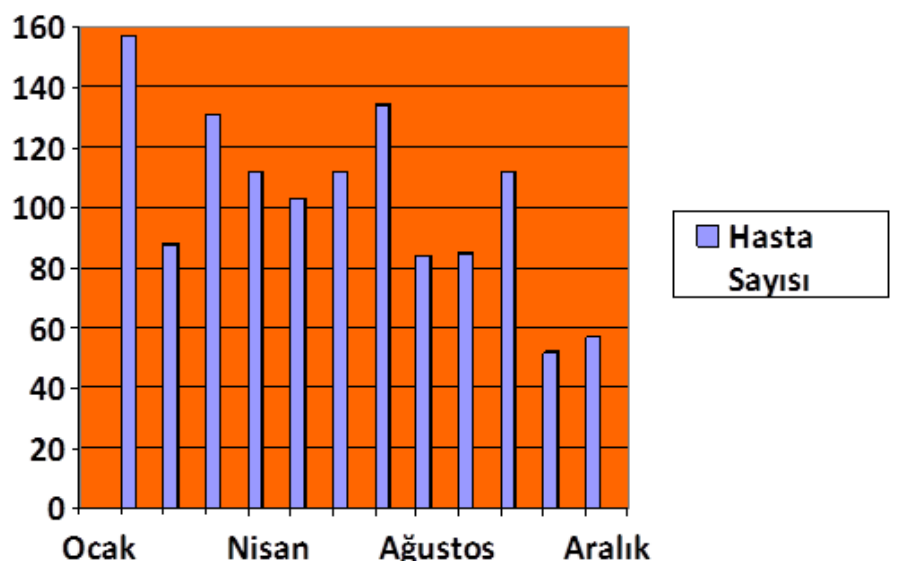

Şekil 1. Ateş nedeni ile başvuruların aylara göre dağılımı.

Değerlendirmeye alınan 1224 olgunu 176'sı (\%14,3) çocuk hasta yaş grubunda iken, 1048 olgu $(\% 85,7)$ erişkin yaş grubundadır. Erişkin hasta grubunda bulunan olgulara istenen Enfeksiyon Hastalıkları konsültasyon sayısı 276 (\%26,3) olarak bulunmuştur. Bu konsültasyonlar sonucu $48(\% 17,3)$ olgu yatırılarak takip ve tedavi edilmiştir. Yatırılarak takip ve tedavi edilen olguların tanıları ise Tablo 2'de verilmiştir.

Tablo 2. Yatırılarak izlenen 48 olgunun dağılımı.

\begin{tabular}{lll}
\hline Tanılar & Sayı & \multicolumn{1}{c}{$\%$} \\
\hline Pnömoni & 14 & 29,2 \\
Üriner enfeksiyon & 8 & 16,7 \\
İnvaziv gastroenterit & 7 & 14,6 \\
Tatarcık humması & 4 & 8,3 \\
Akut bakteriyel menenjit & 2 & 4,2 \\
Yumuşak doku enfeksiyonu & 2 & 4,2 \\
Enfeksiyöz mononukleozis & 2 & 4,2 \\
Akut hepatit A & 2 & 4,2 \\
Riketsiyoz & 1 & 2,1 \\
Yüksek ateş etiyoloji & 6 & 12,5 \\
\hline Toplam & 48 & $100 \%$ \\
\hline
\end{tabular}


Çalışma sonuçlarımıza göre ateşe eşlik eden en sık yakınma boğaz ağrısı $(\% 29,3)$ olarak saptanmıştır. Boğaz ağrısı yakınması olan 510 olgudan tonsillit tanısı alan $113(\% 22,1)$ olguya yapılan Strep A hizlı test (Bio-Merieux, Etoile, Fransa) sonucu $49(\% 43,3)$ olguda pozitif saptanmıştır. Acil Serviste değerlendirilerek enfeksiyon hastalıkları konsültasyonu istenen 113 tonsillit olgusundan $9(\% 7,96)$ tanesi ise enfeksiyöz mononukleoz tanıs1 almıştır. Enfeksiyöz mononukleoz olgularından 2 tanesi periorbital ödem ve genel durum bozukluğu nedenleri ile yatırılarak tedavi edilmiştir. Boğaz ağrısı yanında diğer üst solunum yolu enfeksiyonu bulguları olan hastalara klinik olarak üst solunum yolu enfeksiyonu tanısı konuldu.

Tüm başvuruların $(\mathrm{n}=15280)$ içinde öksürük yakınması olan hastalar çalışmamızda $\% 1,2$ 'lik ( $\mathrm{n}=184)$ bir yer tutmaktadır. Ateş ve öksürük yakınması beraber görülen hastalar ise \%10.3'lük (n=184) yer tutmaktadır. Enfeksiyon hastalıkları konsültasyonu istenen 276 olgudan 14'ü $(\% 5,1)$ pnömoni tanısı ile yatırılarak takip ve tedavi edilmiştir. Nötropenik ateş ile birlikte pnömoni tanısı alan olgularda eşlik eden maligniteler mide kanseri, kronik lenfositer lösemi ve multiple myeloma olup 4 olgudan birisi 4. cü derece metastatik mide kanseri nedeniyle kaybedilmiştir. Diğer olgular ise tedaviye iyi yanıt vermiştir.

Gastrointestinal yakınmalar kusma $(n=168 ; \% 9,6)$, ishal $(n=130 ; \% 7,4)$, bulantı $(n=126$; $\% 7,2)$ ve karın ağrısı $(n=120 ; \% 5,8)$ öksürük yakınmasından sonra en sık saptanan belirtilerdir. İshal yakınması olan 130 olgudan non-invaziv gastroenterit tanıs1 alan olgu sayıs1 $87(\% 66,9)$ olarak bulunmuştur. Enfeksiyon hastalıkları konsültasyonu yapılan ateş ve ishal yakınması olan 43 hastanın 7'si $(\% 16,2)$ yatırılarak takip ve tedavi edilmiştir. İshal etkenleri Tablo 3'de gösterilmiştir. İnvaziv gastroenterit tanısı alan $43(\% 33,07)$ olgunun hiçbirisinde Salmonella ve Shigella enfeksiyonu olmaması dikkat çekicidir. Mikrobiyoloji laboratuarında SS agar yanında selenif F kullanımı bu verinin ardından kullanıma alınmıştır. KKTC Sağlık Bakanlığı istatistiklerinde de Shigella enfeksiyonu lehine veri bulunamamıştır. Ayrıca terminal ileit, invaziv gastroenterit ve ateş tablosu ile seyreden Haziran 2012 ve Temmuz 2012 tarihleri arasında görülen $10(\% 23,25)$ olgunun Yersinia enterokoliti olarak değerlendirilmesi ve iki yıllık süreçte sadece üç aylık bir süre içinde saptanmış olması ise dikkat çekicidir. İnvaziv seyreden $16(\% 37,20)$ olguda ise etken patojen saptanamamıştır.

Tablo 3. İnvaziv gastroenterit etkenleri.

\begin{tabular}{lll}
\hline Etken & Sayı & \multicolumn{1}{c}{$\%$} \\
\hline Yersinia enterokoliti & 10 & 23,25 \\
Rotavirus & 5 & 11,63 \\
Clostridium toksin A-B & 4 & 9,30 \\
Adenovirus & 3 & 6,98 \\
Entamoeba histolytica & 3 & 6,98 \\
Giradia intestinalis & 2 & 4,66 \\
Tanımlanamayan & 16 & 37,20 \\
\hline Toplam & 43 & $\% 100$ \\
\hline
\end{tabular}

Enfeksiyon hastalıkları konsültasyonu istenen ateş, baş ağrısı, oryantasyon bozukluğu veya bilinç kaybı olan 32 hastadan ikisi $(\% 6,25)$ pnömokok menenjiti nedeni ile enfeksiyon kliniğinde yatırılarak tedavi ve taburcu edilmişlerdir. Nöroloji kliniğinde takip edilen bir olgu $(\% 3,12)$ ise iyi tedavi edilmemiş pnömokok meningoensefaliti tanısı ile yatırılmış ve tedaviye cevap vermemiştir. Oryantasyon bozukluğu ve bilinç kaybı nedeni ile takip edilen diğer $29(\% 90,62)$ hasta ise Nöroloji, Beyin Cerrahisi, İç Hastalıkları ve Çocuk Hastalıkları uzmanları tarafından takip edilmişlerdir. Beyin metastazı nedeni ile acil servisimize sevk edilen bir hastada ise intrakranial apse formasyonları düşünülmüş ve mikrobiyolojik incelemede ise Nocardia spp. saptanmıştır. Beyin cerrahisi servisinde yatırılıp takip edilen bu hastada çoklu beyin apsesi vakalarının büyük çoğunluğunda olduğu gibi mortalite ile sonuçlanmıştır.

Ateş nedeni ile yapılan Enfeksiyon Hastalıkları konsültasyonlarında üriner sistem enfeksiyonu olan 8 olgu $(\% 16,66)$ yatırılarak takip ve tedavi edilmiştir. Yumuşak doku 
enfeksiyonu nedeni ile yatırılarak takip edilen iki hastanın bir tanesinde etken patojen Nocardia spp. olarak saptanmıştır. Klinik bulguları ile tatarcık humması tanısı alan 4 olgu $(\% 8,33)$ yatırılarak takip ve tedavi edilmiştir. Ateş nedeni ile yatırılan iki hastada $(\% 4,17)$ akut hepatit A ve bir hastada $(\% 2,08)$ ise riketsiyoz tanısı konulmuştur. Ateş haricinde bulgusu olmayan $6(\% 12,5)$ olgu ise nedeni bilinmeyen ateş etyolojisi araştırmak üzere yatırılmıştır. Bu altı olgunun ikisinde $(\% 4,17)$ endokardit, ikisinde $(\% 4,17)$ ise kollagen doku hastalığ 1 ve ikisinde $(\% 4,17)$ malignite saptanmıştır.

\section{Tartışma}

Araştırma döneminde Acil Servise ateş nedeni ile başvurma oranı \%7,7 olarak bulunmuştur. Üniversite hastaneleri acil servislerine ateş nedeni ile başvurular mevsimsel, coğrafik, sosyoekonomik ya da sağlık sistemine bağlı olarak farkl1lıklar gösterebilir. Ayrıca pandemi ile seyreden domuz gribi, kuş gribi ve coğrafik ve mevsimsel seyreden Kırım Kongo kanamalı ateşi olgularında, ateş ile acil servis başvurularında artış saptanmaktadır [1-4].

Çalışma sonuçlarımıza göre ateşe eşlik eden en sık yakınma boğaz ağrısıdır. Acil servise başvuran hastaların incelendiği bir çalışmada baş ve boyun bölgesindeki yakınmalar ile başvuran hastalarda en sık tanı üst solunum yolu enfeksiyonları (ÜSYE) \%11,5 olarak tespit edilmiştir [5]. Ayrıca, Kalemoğlu ve ark. [6] 2004 yılındaki çalışmasında üst solunum yolu enfeksiyonları tanısı alan hastalar \%24,1 olarak bildirilirken, Taşdelen ve ark. [7] bu oranı \%29,4 olarak bildirmişlerdir. Pediatrik yaş grubunda ateş yanında en sık yakınmalar ise erişkin yaş grubu ile benzerlik göstermekte olup en sık yakınma yine boğaz ağrısı olarak bulunmuştur [8, 9]. Bizim çalışmamızın sonuçları da \%29,3'lük bir oran ile önceki çalışmalar ile benzerlik göstermektedir.

Ateşe eşlik eden öksürük yakınması ile başvuran olgular bu çalışmada ikinci sıklıkta görülmektedir. Center of Disease Control (CDC) 2004 yılı acil servis raporunda, tüm başvuruların \%2,5'luk kısmında öksürük yakınması yer almaktadır [10]. CDC'nin 2003 yılı raporunda ise \%3,2 olarak öksürük yakınması ile başvuru bildirilmiştir [11]. Bizim çalışmamızda ise, tüm başvuruların içinde öksürük yakınması olan hastalar çalışmamızda $\% 1,2$ 'lik bir oran ile daha az gibi görünmektedir. Öte yandan ateş ve öksürük yakınması beraber olan olgular ise \%10,3'lük daha yüksek bir oranda karşımıza çıkmaktadır. Bunun nedeni, hastanemizin referans hastanesi olması nedeni ile daha komplike olguların başvurması olabilir.

Gastrointestinal yakınmalar, öksürükten sonra en sık saptanan belirtilerdir. İshal ile beraber karın ağrısı, bulantı, kusma ve ateş tablosu olan olgularda acil servislerde hastalara nasıl yaklaşılacağı hep tartışma konusu olmuştur [12]. Gastroenterit etkenlerinin incelendiği bir çalışmada Giardia intestinalis en sık etken olarak saptanmıştır [13]. Bizim çalışmamızda ise Yersinia entereokoliti tanısı alan 12 olgu en sık görülen etken olmakla beraber iki ylllık süreçte sadece üç ay içinde saptanmıştır. Yersinia enterokoliti vakalarının arttığı üç aylık süreç içinde yapılan salgın araştırmasında, vakaların altyapı yenilenme çalışmalarının yapıldığı bölgelerde lokalize olduğu saptanmıştır. Gastroenterit olgularının değişik oranlardaki sıklığı incelemenin yapıldığı bölgenin altyap1 şartları, kişilerin eğitim ve hijyen düzeyleri gibi bir takım özelliklere göre farkl1lıklar göstermektedir [14]. KKTC'de alt yapı sistemi foseptik kuyusu sistemi olup, özellikle sıcak mevsimlerde su sıkıntısı çekilmektedir. Yaz aylarındaki artış bununla ilişkili olabilir.

Acil serviste enfeksiyon hastalıkları konsültasyonu istenen santral sinir sistemi enfeksiyonları incelendiğinde etken S. pneumoniae ve Nocardia spp. olarak saptanmıştır. Çalışmamız en sık görülen etkenlerle beraber nadir etkenlerin de görülebileceğini ortaya koymuştur. Bu çalışmanın yapıldığı süre içinde, tüberküloz menenjiti saptanmamıştır. $\mathrm{Bu}$ KKTC'de BCG aşısı uygulanmaması gibi bir riskin yanında, aktif akciğer tüberkülozu sayısının da çok az olması ile ilişkili olabilir. Bir ada ülkesi olması ve diğer ülkelerden tatil amacı dışında gelen tüm bireylerin çalışma ve oturma izni alırlarken tüberküloz 
açısından incelenmesi nedeniyle, ithal vakalar tedavi altına alınırlar. Bu nedenle ülkenin tüberküloz indeksi düşüktür.

Üriner sistem enfeksiyonu tanısı alan hastaların idrar kültürlerinde birçok çalışmada olduğu gibi E. coli sıklıkla saptanmıştır. Bir çalışmada acil servis hekimleri tarafından alt üriner sistem enfeksiyonunda kinolon reçete edilmesi araştırılmış ve en sık reçete edilen antibiyotik olduğu saptanmıştır [15]. Acil Serviste idrar kültür antibiyogram testi isteminin yapılması ve ardından tedaviye bölgenin antibiyotik direncinin bilinerek başlanmasının önemi akılda tutulmalıdır. Yayın aşamasında olan, KKTC'de 160 hastada yapılan idrar kültür antibiyogramında; siprofloksasin direnci \%34,9, ampisilin-sulbaktam direnci $\% 37,7$ ve trimethoprim-sulfamethakzasol direnci $\% 45,8$ olarak saptanmıştır.

Hastaların ateş nedeni ile acil servislere başvurularının altında her zaman enfeksiyöz ajanlar sorumlu değildir. Curaçao Karayib adalarında yapılan bir çalışmada, acil servise ateş nedeni ile başvuran hastaların incelendiği bir yazıda \%5,2 oranında enfeksiyon dış1 tanılar konmuştur $[16,17]$. Ancak acil servislerdeki bu olguların pratisyen ya da acil uzmanları tarafından bildirilmiş olması ve ileri takiplerinde bakıldığında tanı konulamamış enfeksiyonlar olabileceği de unutulmamalıdır. Bizim çalışmamız da ise hastalar enfeksiyon uzmanı tarafından değerlendirilmiş ve ileri tanı ve tedavileri aynı enfeksiyon uzmanı tarafından izlenmiştir. Ateş ile başvuran 1224 hastadan 276 olguda enfeksiyon uzmanı konsültasyona çağrılmıştır. Buradaki 276 hastanın sadece 4'ünde $(\% 1,44)$ non-enfeksiyöz etiyoloji saptanmıştır. Bu oranın önceki yayınlardan çok düşük olmasının nedeni ise ateş ile başvuran hastaların tümünün non-enfeksiyöz etiyolojisinin bilinmemesidir.

KKTC, Dünya Sağlik Örgütü ülkeler listesinde bulunmamaktadır. Az gelişmiş ve veya gelişmekte olan ülkelerde ateşli hastalıkların etiyolojisi ve epidemiyolojisi az bilinmektedir. Oysa KKTC'nin Akdeniz'in ortasında, subtropikal iklime sahip turistik bir ada ülkesi olup, ülkedeki üniversitelere dünyanın çeşitli yerlerinden öğrenci geldiği göz önüne alındığında, adada ateş sebebi olabilecek nedenlerin bilinmesi ve enfeksiyöz ajanların tanımlanmış olması, özellikle acil servislerde tanı ve tedavi sürecinde önem taşımaktadır. Bölgeye ait epidemiyolojik verilerin bulunması sadece ateş nedeni ile başvuran hastaların değerlendirilmesinde fayda sağlamakla kalmaz. Ayrıca, acil servislerde uygunsuz antibiyotik kullanımı ve direnç gelişimine engel olunmasında da anahtar rol alabilir [17,18]. Bu bilgiler, adada çalışan hekimlere acil durumlarda ilk etapta düşünmeleri ve önlem almaları için gerekli olan vakit ve kolaylık kazandıracak bilgiler olduğu kadar, turist sağlığı açısından da, ülkelerine döndüklerinde ortaya çıkabilecek ateşli hastalıkların ayırıcı tanısı için de önem taşımaktadır [19].

Ayrıca Kıbrıs'ta 1984-1985 yıllarında tatarcık sinekleri nedeni ile Birleşmiş Milletler askerleri arasında Tatarcık humması salgını yaşanmıştır [20]. KKTC'de adaya ilk kez gelenlerin karşılaştığı bir ateş nedeni ise tatarcık (küpdüşen sineği) 1sırığına bağlı ortaya çıkan ateşli tablodur. Yerleşik yaşayan ada halkının çocukluk çağında bu hastalığı geçirdiği bilinmektedir [20, 21]. Benzer salgınların tanınması ve tanımlanması için de epidemiyolojik verilerin değerlendirilmesi gerekir.

Hastanelerin acil servisleri her yaş grubu ve her türlü olgunun başvurduğu bir birim olarak çalışmaktadır [22]. Acil servis hekimlerinin başvuran hastanın aciliyeti konusunda bir bilgi sahibi olması, gerçekten acil olan olgularda hayat kurtarıcı özelliğe sahiptir. Triaj uygulaması acil servislerde uygulandığı zaman ortaya çıkan veriler acil servis yoğunluğunun poliklinik hastalarından kaynak aldığını göstermektedir. Bir çalışmada acil servisde triaj eğitimi alan hemşirelerin eğitim öncesi Emergency Severity Index (ESI) olarak tanımlanan sınıflamada doğru belirleme oranları \%30 iken eğitim sonrası bu oranın \%80'e yükseldiği saptanmıştır[23]. Ateş etiyolojilerini göz önüne aldığımız zaman ateş nedeni ile hastanın acil servise geldiği andan itibaren ESI ile değerlendirilmesi sepsis, menenjit ve diğer enfeksiyon acilleri tablolarında sonucun daha farklı seyretmesini, tedavide başarı oranlarının artmasını sağlayacaktır. 
Kıbrıs'a ait ateşli hastalıklar epidemiyolojisi ile çok az sayıda yayın vardır. Tatarcık humması salgını 1985 yılında yaşanmıştır [24]. Ayrıca Q ateşi ve 2009 yılındaki H1N1 pandemisi ile ilgili birer yayın mevcuttur $[25,26]$. Bizim çalışmamızda hiç Q ateşi görülmemiştir. Ailevi Akdeniz Ateşi (FMF) Akdeniz coğrafyasında acil servislerde sık karşılaşılan bir ateşli durumdur. Türklerde, Araplarda, Ermenilerde, İsraillilerde olduğu kadar, yapılan bir çalışmada Rum kökenli Kıbrıslılarda FMF mutasyonlarının sık olduğu gösterilmiştir [27]. Bu bilgiler 1şı̆̆ı̆nda FMF'in acil servislerde karşılaşılması beklenen bir durumdur. Bu retrospektif çalışmanın yapıldığ 1 dönemde acil servis kayıtlarında FMF tanısı olmaması nedeni ile, konunun akılda tutulması ve gereğinde araştırılması gerekmektedir.

Sonuç olarak çalışmamızda, KKTC'de acil servise ateş nedeni ile başvuran hastaların etiyolojik etkenleri ilk kez tanımlanmıştır. Bulgularımız bir çok acil servis de olduğu gibi en sık ÜSYE olarak saptanmıştır. Acil servis ve ateş ilişkisi göz önüne alındığı zaman önem arz eden hayatı tehdit edici enfeksiyonların tespit edilebilmesidir. Ancak, çalışmamızın üçüncü basamak bir referans merkezde yapıldığı göz önüne alındığında, bulgularımız, birinci-ikinci basamak sağlık merkezlerinde sonuç alınamamış, uygun tanı ve tedavi almamış, gecikmiş ya da ciddi ve acil durumları yansıtıyor olabilir. Bu nedenle, tüm kesimleri kapsayan daha geniş bir çalışmaya ihtiyaç olduğu ve birinci basamak hekimlerin işbirliğine ihtiyaç olduğu da açıktır.

\section{Kaynaklar}

1. LaRussa P. Pandemic novel 2009 H1N1 influenza: what have we learned?Semin Respir Crit Care Med 2011; 32: 393-9.

2. Hoffman SJ. The evolution, etiology and eventualities of the global health security regime. Health Policy Plan 2010; 25: 510-22.

3. Chen JM, Chen JW, Dai JJ, Sun YX. A survey of human cases of H5N1 avian influenza reported by the WHO before June 2006 for infection control. Am J Infect Control 2007; 35: 351-3.

4. Bursalı A, Tekin S, Orhan M, Keskin A, Özkan M. Ixodid ticks (Acari: Ixodidae) infesting humans in Tokat Province of Turkey: species diversity and seasonal activity. J Vector Ecol 2010; 35: 180-6.

5. Polat O, Kabaçam G, Güler İ, Ergişi K, Yıldız A. İbn-İ Sina Hastanesi Acil Servisi'ne Başvuran Hastalerın Sürveyans Analizi. Tr J Emerg Med 2005; 5: 7881.

6. Kalemoğlu M, Keskin Ö. Gata Haydarpaşa Eğitim Hastanesi Acil Servisinin Tıbbi Veri Dökümü ve Hasta Karakteristiği. Tr J Emerg Med 2002; 2: 2.

7. Taşdelen-Fışgın N, Genç S, Tanyel E, Yılmaz H, Baydın A, Tülek N. Acil Servise Başvuran Hastalar Araındaki İnfeksiyon Hastalıklarının Sıklığının İncelenmesi. Klimik Dergisi 2006; 19: 110-3.

8. Luszczak M. Evaluation and management of infants and young children with fever. Am Fam Physician 2001; 64: 1219-26.

9. Makoni M, Mukundan D. Fever. Curr Opin Pediatr 2010; 22: 100-6.

10. McCaig LF, Nawar EW. National Hospital Ambulatory Medical Care Survey: 2004 Emergency Department Summary. Adv Data 2006; 1-29.

11. McCaig LF, Burt CW. National Hospital Ambulatory Medical Care Survey: 2003 Emergency Department Summary. CDC 2005

12. Eken C. Güncel Klinik Yaklaşım Önerisi: Acil Serviste Akut İshalli Hastaya Yaklaşım. Turk J Emerg Med 2011; 11: 33-9.

13. Oğuztürk H, Eren ŞH, Korkmaz İ, Güven FMK. Prevalence of Microorganisms in Patients Presented with Gastroenteritis to the Emergency Department Turk J Emerg Med 2008; 8: 114-20.

14. Bozdemir MN, Kuk S, Yıldız M, Ateşçelik M, Baştürk M, Kılıçaslan İ. Acil servise başvuran ishalli hastaların değerlendirilmesi. Fırat Tıp Dergisi 2007; 12: 118-20. 
15. Güneysel Ö. Alşen S, Eroğlu S, Akıcı A. Acil Servislerde Çalışan Hekimlerin İdrar Yolu Enfeksiyonlarının Tedavisinde Kinolon Kullanımı Alışkanlıklarının Değerlendirilmesi. Turk J Emerg Med 2006; 6: 101-7.

16. Limper M, Gerstenbluth I, Duits AJ, van Gorp EC. Epidemiology of febrile diseases in the emergency department of a Caribbean island: the Curaçao experience. West Indian Med J 2012; 61: 76-80.

17. Limper M, Eeftinck Schattenkerk D, de Kruif MD, van Wissen M, Brandjes DP, Duits AJ, van Gorp EC. One-year epidemiology of fever at the Emergency Department. Neth J Med 2011; 69: 124-8.

18. Knott JC, Tan SL, Street AC, Bailey M, Cameron P. Febrile adults presenting to the emergency department: outcomes and markers of serious illness. Emerg Med J 2004; 21: 170-4.

19. de Valliere S. What's new in travel medicine? Rev Med Suisse 2008; 4; 1218-21.

20. Süer KH, Kaptanoğlu A. Kıbrıs'a özgü bir vektör: Küpdüşen sineği deri bulguları ile tatarc1k hummas1. NEMJ 2011; 1: 14-7.

21. Kaptanoğlu AF, Özgöl Y, Tinazlı M. Kuzey Kıbrıs’ta Üniversite Hastanesi Acil Servisine Dermatoloji Başvuruları. JAEM 2012; 11: 137-40.

22. Demircan C, Çekiç C, Akgül N, Odabaşı A, Çalışır N, Kıyıcı S, Yuvanç U, Haki C, Keskin M. Acil Dahiliye Ünitesi Hasta Profili: 1 Y1llık Deneyim. Uludağ Üniversitesi Tıp Fakültesi Dergisi 2005; 31: 39-43.

23. Çınar O, Çevik E, Salman N, Cömert B. Emergency severity index triaj sistemi ve bir üniversite hastanesi acil servisinde uygulama deneyimi. Turk J Emerg Med 2010; 10: 126-31.

24. Konstantinou GN, Papa A, Antoniadis A. Sandfly-fever outbreak in Cyprus: are phleboviruses still a health problem? Travel Med Infect Dis 2007; 5: 239-42.

25. Loukaides F, Hadjichristodoulou C, Soteriades ES, Kolonia V, Ioannidou MC, Psaroulaki A, Tselentis Y. Active surveillance of Q fever in human and animal population of Cyprus. BMC Infect Dis 2006; 6: 48.

26. Koliou M, Soteriades ES, Toumasi MM, Demosthenous A, Hadjidemetriou A. Epidemiological and clinical characteristics of influenza $A(H 1 N 1) v$ infection in children: The first 45 cases in Cyprus, June - August 2009. Euro Surveill 2009; 14.

27. Deltas CC, Mean R, Rossou E, Costi C, Koupepidou P, Hadjiyanni I, Hadjiroussos V, Petrou P, Pierides A, Lamnisou K, Koptides M. Familial Mediterranean fever (FMF) mutations occur freugently in the Greek-Cypriot populaion of Cyprus. Genet Test 2002; 6: 15-21. 